\title{
Analysis of underachieving students' problems and the given guidance
}

\author{
Rosna Pentiaratih Supendi \\ SMK - SMAK Bogor \\ Jl. Binamarga I, Kota Bogor \\ E-mail: rosnasupendi@gmail.com
}

Received: March 6, 2020 ; Revised: May 7, 2020; Accepted: May 28, 2020

\begin{abstract}
Student learning success can be seen from academic achievement. However, not all students can achieve maximum performance despite having a high IQ score. Many of the students do not show optimal results or they are usually called underachievers. Many backgrounds affect underachieving students. This study used descriptive statistical methods of 38 students of class X of SMK-SMAK Bogor to analyze the problem of underachieving students. The research results show that guidance is needed for underachieving students to be able to overcome their problem and obtain optimal learning achievement.
\end{abstract}

Keywords: student, underachiever, iq, guidance and counseling

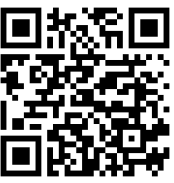

This is an open-access article under the CC-BY-SA license.

\section{Introduction}

Students, in living their daily lives, cannot be separated from education. Education serves to improve the quality of students themselves, both individually and in groups, both physical, spiritual, and maturity of thinking. Education is the basis for the progress and survival of individuals. Through education, individuals obtain information and knowledge that can be used to develop themselves in accordance with their abilities and opportunities.

In the National Education System Law No. 20 of 2003 Chapter 2 Article 3 mandates that education must function to develop capabilities and shape the character and civilization of a dignified nation in order to educate the life of the nation, to develop the potential of students to become human beings who believe in and have faith in God Almighty, have good morality, are healthy, knowledgeable, capable, creative, independent, and are democratic and responsible.

Efforts to develop individual potential in education are carried out with reference to the learning process. The learning process is a reciprocal activity between a teacher and students in which there are programs and learning activities to facilitate students in achieving optimal development.

One indicator of the achievement of student learning success can be seen from the results obtained. Learning outcomes are benchmarks that determine the level of success of students in understanding a subject matter that is measured by tests and written in the form of grades. Learning outcomes have an important role in the learning process, because it will provide 
information to teachers about the progress of students. In fact, not all students can achieve learning outcomes in accordance with their potential, many of the students do not show optimal results.

The learning process undertaken by students in schools is influenced by various factors. Learning outcomes achieved will depend on the interaction of various interrelated factors. One factor that can affect learning outcomes is the level of intelligence (IQ).

Dalyono (Djamarah, 2002: 160) stated that a person who has good intelligence (high IQ) is generally easy to learn and the results tend to be good. Otherwise, people with low intelligence tend to experience difficulties in learning, think slowly, and have low achievement. Djamarah (2002: 160) revealed that various studies mentioned that there is a close relationship between IQ and learning achievement in school. Students who have a level of intelligence above 120 in the intelligence test scores are predicted to have no difficulty in learning and transition in school achievement.

Based on these statements, the level of intelligence possessed by a student should be a guarantee to achieve maximum learning outcomes. However, in reality, many students who have a high level of intelligence have difficulty in completing school assignments and getting learning results below their potential. Students with this condition are usually called underachieving students.

According to Prayitno and Erman Amti (2004: 280) underachiever is identical to academic delay which means that "the students are estimated to have high intelligence, but cannot use it optimally". No motivation in learning often becomes an obstacle to children's learning. This means that if students lack achievement motivation, they may become underachievers. In line with Rimm's statement (2000: 218) that when students do not show their potential, then they are underachievers.

In class X of SMK-SMAK Bogor, there are 38 students who are underachievers. Some other evidence describing the number of underachieving students is illustrated in the following study. Achir's study results (Munandar 2002: 336) in two high schools in Jakarta found 39\% of students classified as underachievers were identified based on intelligence tests and creativity tests. Nurhayati (2003: 3) who conducted a study to students of SMUN 4 Bandung in the 2003/2004 academic year found that out of 250 students who had intelligence score of 120 and above, 16 students $(12.8 \%)$ were underachievers with an average score of 6 and below. While the average learning achievement obtained by 306 students of class XI, as many as 76 students or approximately $24.8 \%$ were included underachievers.

Rimm and Whitmore in (Utami Munandar, 2002: 38) revealed that the characteristics of underachieving students are as follows: a) Primary characteristics are characterized by a sense of low self-esteem; they do not believe in their abilities and feel unable to do what parents and teachers expect towards them, b) Secondary characteristics are characterized by avoidance behavior. Low self-esteem results in non-productive avoidance behavior both at school and at home. Underachieving students avoid efforts to get achievement by stating that learning is an activity that is of no use. The avoidance behaviors include blaming schools to avoid their responsibility to achieve something, c) Tertiary characteristics, because underachieving students avoid effort and achievement, to protect their vulnerable self-esteem, tertiary characteristics arise in the form of poor learning habits.

Underachiever is a very complex problem in the world of education. Underachiever leads to the relationship of various factors that lie behind it. Natawidjaja (1985) stated that there are two factors that can influence student achievement, namely internal factors and external factors. Internal factors in learning are factors that exist in individuals that include intelligence, personality, talent, motivation, learning methods, and attitudes and learning habits, while external factors that affect learning in individuals are family, school, and society.

The existence of guidance and counseling services has an important role so that the school counselor can help students recognize and accept themselves, recognize and accept the 
surrounding dynamically and positively, and be able to make decisions, direct and realize themselves effectively and productively according to their role they play in the future (Prayitno, et al, 1997: 19). Based on the background of the problems that have been described above, the purpose of this study is to: (1) Determine the problem of underachieving students of SMKSMAK Bogor and; (2) Knowing the guidance that can be done in accordance with student needs.

\section{Method}

This research used descriptive statistics in its analysis. Descriptive statistics are statistics used to analyze data by describing data that have been collected as they are without intending to make conclusions that apply in general or generalization (Sugiyono, 2011: 207-208). The main purpose of this study was to describe the subject under study carefully and systematically using quantitative data (A. Muri Yusuf, 2005: 83). The subjects of the study were grade X students who included the criteria of underachieving students. Underachieving student criteria were determined by comparing IQ scores with academic achievement obtained from the average value of their school reports / learning achievements (Rimm, 2000: 218). Data were collected with a number of instruments in the form of interview guidelines, and the AUM (Problem Expressing Tool). The data obtained were processed systematically and presented in a descriptive form.

The research subjects were 38 students of class X of SMK-SMAK Bogor which included criteria for underachieving students. Underachieving student criteria were determined by comparing IQ scores with learning outcomes in the odd semester of the 2019/2020 school year. The thirty-eight students were students with an IQ above 120 and occupying the 7 th lowest position in their class.

\section{Findings and Discussion}

From the results of interviews and questionnaires that have been collected, several factors that cause students who have high IQ scores to get low learning outcomes are obtained. These factors include:

1. Teacher's explanation is not clear

2. Teacher's writing is difficult to read

3. The material taught is not the same as in the book

4. Test questions sometimes do not match with what is taught

5. Students are blank when working on exam questions

6. Students are not able to memorize well

7. Students are careless in working on problems

8. Students are lazy

9. Students don't like the lesson

10. Students are don't have click friends

11. Students do not feel confident (think that someone else is better)

12. Students do not able to adapt in the new school environment

13. Students are do not understand the material being taught

14. Students are too tired with their tight schedule in school

15. Students cannot set the time

16. The material presented is not interesting

17. Students lack worship

18. Students lack motivation

19. Students are not interested in studying in the school

20. Students play with their cellphones too much

21. Students underestimate the lesson

22. There is no support from the surrounding 
23. Students have too many assignments so there is no time to study

24. Students give up easily when finding a difficult problem

Rimm (2000: 5) also mentioned that the characteristics of underachieving students are namely poor expertise in doing school work, poor study habits, having problems with peer acceptance, poor concentration in activities at school, being unable to regulate themselves both at home and at school, being easily bored, having good language skills but are bad at writing, being impatient, being busy with their own thoughts, being not honest, often criticizing themselves, liking to joke in class and behaving abnormally. Based on the analysis of the results of the psychological test related to the work attitude of underachieving students, the following data are obtained:

Table 1. Percentage of Work Attitude and Achievement (High Category) of Underachieving Students

\begin{tabular}{lc}
\hline \multicolumn{1}{c}{ Work Attitude } & $\%$ \\
\hline Speed & 47,36 \\
Stability & 57,89 \\
Accuracy & 68,42 \\
Endurance & 55,26 \\
Acbievement & 18,42 \\
\hline
\end{tabular}

Table.1 shows that more than $50 \%$ of underachieving students have high stability, accuracy and endurance at work. A good work attitude can support students to achieve maximum results. However, the achievement indicated by underachieving students is only $18.42 \%$ and is in the low category. It can be said that these students do not have a strong motivation to achieve their maximum performance in accordance with their potential. After the interview, it is revealed that this good work attitude will emerge if the students like what they are doing. When they are bored and do not like what they do, then they will show the opposite work attitude. That's what happens when they study subjects in school. Twenty nine of the 38 underachieving students interviewed are not interested in continuing their education at SMK-SMAK Bogor. This interest also influences their low achievement scores.

Based on the problems related to underachieving students, efforts should be made to take precautions so that these problems do not interfere with student development and have longterm effects. Therefore, appropriate guidance programs need to be developed in order to help solve the problem of underachievers in schools as a preventive and developmental effort.

The stages of program that can be done by counselors are as follows:

1. Conducting exploration to inventory students who are in the underachiever category through observation, documentation study and interviews about their subject teachers

2. Preparing a measuring tool to find out the profile of underachieving students

3. Measuring the factors causing them to be underachievers

4. Analyzing test measurement data about underachieving student profiles

5. Conducting a discussion and analysis of all data obtained

6. Making a picture of the underachieving student profile based on the overall data obtained

7. Developing a guidance program to address underachieving students' problems

8. Implementing a guidance program

9. Conducting program evaluations and revisions in accordance with the program findings and results.

Conclusion (and implications, recommen-dations, or suggestions, if any) 
The problem profile of underachieving students is one of the portraits of student development in a learning process. The condition of underachieving students can show their academic self-concept, learning motivation as well as their own attitudes and study habits. The profile of the underachieving students can be used as a reference for the implementation of guidance and counseling services. In addressing the problem of underachieving students, school counselors can do the following:

1. Cooperating with homeroom teachers, subject teachers and other counselors in identifying students who show symptoms of underachiever.

2. Conducting a thorough analysis of underachieving student problem profiles.

3. Developing guidance and counseling programs for underachieving students.

\section{References}

Ahmadi, Abu dan Widodo, S. 2003. Psikologi Belajar, Jakarta : Rineka Cipta.

Depdiknas. (2007). Penataan Pendidikan Profesional Konselor dan Layanan Bimbingan dan Konseling dalam Jalur Pendidikan Formal. Bandung : Jurusan Psikologi Pendidikan FIP UPI Bandung Bekerjasama dengan PB.ABKIN.

Del Siegle \& McCoah, DB. (2008). Understanding Underachievement: Recent Research on Underachievement. [Online]. Tersedia di: https://www.researchgate.net/publication/325687711_Understanding_Underachievemen t/link/5c41e9f8299bf12be3d191c4/download

Djamarah, Syaiful Bahri. (2002). Psikologi Belajar. Jakarta: PT Rineka Cipta.

Hurlock, E. B. (1995). Developmental Psychology: A Life Span Approach. Fifth Edition. McGraw-Hill, Inc.

Makmun, Abin Syamsudin (2004). Psikologi Kependidikan: Perangkat Sistem Pengajaran Modul. Bandung: Penerbit PT Remaja Rosdakarya

Nurihasan, Juntika. (2005). Strategi Layanan Bimbingan dan Konseling. Bandung: Refika Aditama.

Ahmadi, Abu dan Widodo, S. 2003. Psikologi Belajar, Jakarta : Rineka Cipta.

Robinson, Linda. (2006). Combining Achievment Barriers for Adolescent Underachieving Learners. Journal of Cognitive Affective Learning, 2(2) (Spring 2006), 27-32

Rimm, Silvia. B. (1986). Underachievement Syndrome Cause and Curse. Watertown: Apple Publishing.

Rimm, Sylvia. (2002). Why Bright kids Get Poor Grades. Alih Bahasa: A. Mangunhardjana. Jakarta: Grasindo

Sulistiana, D. \& Muqodas, I. (2015). Upaya Bimbingan bagi Siswa Underachiever. Metodik Didaktik Vol. 10, No. 1, Juli 2015, from https:// ejournal.upi.edu/index.php/MetodikDidaktik/article/view/3228

Surya, M. (2003). Psikologi Pembelajaran \& Pengajaran, Edisi Revisi. Bandung: Yayasan Bhakti Winarya. 